\title{
'Lesser-used' languages in historic Europe: models of change from the 16 th to the 19th centuries
}

\author{
R. A. HOUS T O N \\ Department of Modern History, University of St. Andrews, St. Andrews \\ KY16 9AL, Scotland, UK. E-mail: rah@st-andrews.ac.uk
}

\begin{abstract}
This article charts and tries to explain the changing use of 'minority' languages in Europe between the end of the Middle Ages and the 19th century. This period saw the beginnings of a decline in the use of certain dialects and separate languages, notably Irish and Scottish Gaelic, although some tongues such as Catalan and Welsh remained widely used. The article develops some models of the relationship between language and its social, economic and political context. That relationship was mediated through the availability of printed literature; the political (including military) relations between areas where different languages or dialects were spoken; the nature and relative level of economic development (including urbanization); the policy of the providers of formal education and that of the church on religious instruction and worship; and, finally, local social structures and power relationships. The focus is principally on western Europe, but material is also drawn from Scandinavia and from eastern and central Europe.
\end{abstract}

\section{Introduction}

Modern Europe has many linguistic boundaries. In the west, there is a sort of 'fault line' between the speakers of Romance languages, such as French and Italian, and Teutonic ones such as German. In the east, there are pockets that contain almost unique languages, such as Finnish and Magyar. However, there are subtler differences too, which can be seen from a map of 'lesser-used languages' provided by an EU-funded body called the 'Bureau for Lesser Used Languages' whose offices are in Brussels and Dublin. ${ }^{1}$ This late-20th-century pattern of great linguistic variation has deep historic roots. Italy had a relatively uniform written language from the late middle ages, but a great diversity of spoken tongues: just 
$2.5 \%$ of Italy's population spoke 'Italian' (Tuscan) with any fluency in 1861; seven out of ten of the inhabitants of Wales were monoglot Welsh speakers in 1800 , and as late as the 1880 s four-fifths were habitual Welsh speakers ( $30 \%$ spoke no English); and at least a fifth of the population of France did not speak 'French' (langue d'oïl) in 1863.

The last 500 years has seen linguistic standardization and a reduction in the proportions of Europeans speaking 'non-standard' languages. All of these declined, but to different extents. Success stories were, to widely differing degrees, Welsh and Catalan; while Irish and Scots Gaelic (a branch of Q-Celtic) were among the least enduring; and Breton and Galician (gallego) come in between. This chapter charts and tries to explain that change by developing some models of the relationship between language and its social, economic and political context. That relationship was mediated through the availability of printed literature; the political (including military) relations between areas where different languages or dialects were spoken; the nature and relative level of economic development (including urbanization); the policy of the providers of formal education and that of the church on religious instruction and worship; and, finally, local social structures and power relationships. There is no single explanation of language change, but the interactions between the influences just mentioned were a powerful force in shaping the cultural geography of early modern Europe.

'Minority', 'lesser-used' or 'non-standard': the way a language is described illuminates the complexity of the processes by which cultural change took place. ${ }^{2}$ Some languages, which are 'lesser used' now, were extensively spoken in the early modern period. Nor can they always be described as 'minority'. For one thing, what later became the dominant language may not have been the tongue of a majority. For another, 'minority' may refer to their status in political units, which were still being formed. For this reason the geographical dichotomy between 'regional' and 'national' languages is similarly problematic. Finally, the social domains in which a tongue is used may be as important as its geographical extent. Terms that serve modern sociolinguists may not help the historian.

A word such as 'subordinate' does not accurately describe these languages either. It purports to describe the outcome of a process that was not always successful and it is value-loaded. Even words that are apparently value-free have a history and may create a bias in perception. As David Bell notes, the term 'patois ... carries more than a whiff of the farmyard, suggesting a half-formed, earthy, unsophisticated language, caught part way between animal grunts and true human speech, a language of people not suited for political participation'. ${ }^{3}$ As used in modern France, the word 'Occitán' has powerful political connotations. Language use most definitely has political dimensions, but one argument of this article is that the variable fortunes of languages cannot all be explained by the interventions of governments. 


\section{Models of language change}

To flourish, any language or dialect needs to be used in literature or in some other written and spoken domain. If used in literature, it needs a market, for language and literacy are closely related. In areas of Europe where the language of everyday life was not that of education, contact with outside authority or printed literature, literacy tended to remain low. The west of Ireland is an example. Roughly 55-60\% of Ireland's people born in the 1770s spoke only Irish. Three quarters of those in the 12 counties of Munster, Connacht and Donegal (with $45 \%$ of the population) were Irish speakers at the end of the 18th century, compared with just $10 \%$ in the remaining 20 counties with 55\% of Ireland's people. ${ }^{4}$ Irish speaking was low and literacy probably high in north-east Ireland even in the early 18 th century because of the prevalence of English-speaking Presbyterians, many of them of Scots origin or descent. ${ }^{5}$ In this region, different religious priorities, a more balanced wealth distribution and greater aggregate prosperity also contributed to superior attainments.

Irish was an oral and manuscript language, writing being confined to a very small learned class (almost a caste) in the 16th and 17th centuries. English possessed these attributes, but it was also a printed language and the medium of education. English spread rapidly outside elite circles from the end of the 18th century because it was the language of commerce and government. Language shifts can occur without changes in literacy (and vice versa), but the two seem to have been associated in Ireland. During the 18th century, Dublin publishers, using a phonetic spelling based on English language orthography, developed printed literature for Irish speakers. This helped bring about growing English language literacy, but it also contributed to the decline of spoken and written Irish because print-literacy in Irish was secured through English, even for Irish speakers. There were almost no secular works printed in Irish during the 18th century. Religious works are better represented. Bishop Carswell's translation of Knox's Book of Common Order (1567) was the first printed text in Gaelic, but was in classical common Gaelic rather than the dialects most people spoke. ${ }^{6}$ Both the first Protestant works and Bedell's Bible in Irish appeared in the 1680s. However, most of the Gaelic religious output of the 18th century was printed abroad and it was all Catholic. ${ }^{7}$

North-west France and Wales experienced different fortunes. There were no printed religious works other than in langue d'oil, Protestant or Catholic, before the mid-17th century. Thereafter, Catholics used printed religious literature in Breton to further the Counter Reformation, thus fuelling the development of reading and writing in the language of everyday speech. Breton was not the language of formal education, but it was part of everyday religious life and instruction. ${ }^{8}$ This helped secure higher levels of literacy, as did the existence from 
the end of the 17th century of popular recreational literature in Breton. It also gave the tongue permanence, for in 1807 nearly a million people regularly spoke Breton. ${ }^{9}$ It was only after the First World War that French really penetrated Lower Brittany and, as late as 1952, 100000 people said they knew no French and another 700000 generally expressed themselves in Breton. ${ }^{10}$

Breton endured, but areas where it was widely used still had lower literacy than the French-speaking départements immediately adjacent. Brittany was also a part of France which, as late as the 1870s, had high proportions of men and women who could read but not write, suggesting that the advantages conferred by attachment to print culture brought only a restricted literacy. Using patois or a separate tongue was part of a cultural preference for oral communication. The same is true of southern France, where langue d'oc (also known as Languedocien) gradually gave way to langue d'oil. Here, variants such as Provençal, Gascon or Moundi had no written form and the dialect versions of French used for education and administration were not commonly spoken. In southern France, literacy and knowledge of French were basically the same thing from the 16th century, French being the written language of government, army, church and courts. ${ }^{11}$ Languedocien became stigmatized as the language of ignorance. In 17th-century Aquitaine Protestants were keener to have education in French so that their people could read biblical texts, compounding a religious divide with a linguistic one because Catholics favoured religious instruction in patois. ${ }^{12}$ Because Protestantism drew disproportionately from certain social groups, social divisions were also accentuated. Indeed, Calvinists were active spreaders of langue d'oül throughout Languedoc, just as they were of English in late-16th and early-17th-century Scotland. ${ }^{13}$

While the implications for literacy could be significant, the motors of linguistic standardization are complex. At one level, the use of langue d'oil was actively promoted. A 'College of the four nations' was set up under Louis XIV to educate the sons of landowners from the culturally separate, geographically distant and politically suspect corners of France. The Revolutionary government after 1789 continued this policy, suspecting non-French speakers and dialect speakers of federalist and counter-revolutionary intentions. An investigation of 1790 led by Abbé Henri Grégoire revealed some striking facts about language use: French was the dominant language in just 15 of 89 departments; 6 million Frenchmen could not understand French at all; a further 6 million could understand it, but spoke it only imperfectly; 30 patois were spoken plus foreign languages such as Flemish or German or Basque (which is unique here in not being Indo-European); only 3 million could speak French 'properly'. Initially this brought awareness of linguistic diversity, but within a few years the eradication of patois became the government's ultimate goal because it seemed to impede the message of the Revolution. $^{14}$ 
Welsh fared slightly better than Breton and significantly better than Scots and Irish Gaelic. As a result of an early, conscious and energetic response to the opportunities of print, the flourishing medieval bardic tradition was modified to be encapsulated in new printed literary traditions, especially through religious works. There was a full Bible from 1588 (Prayer Book and New Testament by 1567), which standardized and gave permanence to Welsh as a language of reading and, to a lesser extent, writing. Welsh-language printing flourished, giving rise to 500 titles in 1660-1730 and a total of perhaps 3000 works before 1820 . With a population ten times the size, Ireland could only boast 200 works in Irish before 1800. ${ }^{15}$ Scotland did not have a Gaelic New Testament until 1767 and there was no complete Gaelic Bible until 1801. ${ }^{16}$ For comparison, the complete Bible was first available in Dutch in 1526, in German in 1530, 'Italian' in 1532, 'French' in 1535, Swedish in 1541, Danish in 1550, Icelandic in 1584 and Finnish not until 1642, although there was a New Testament in 1548. By 1800 fully 31 editions of the Bible had been printed in Welsh. ${ }^{17}$

The success of Welsh as a religious language was because it was never associated with opposition to Protestantism and political centralization in the 16th and 17th centuries. The Welsh bardic tradition of the 17th century actually supported the royalist, Anglican establishment. ${ }^{18}$ Until the tradition died out in the 17th and early 18th century, Irish and Scottish bards promoted particular nobles and (though not invariably in Scotland) the Catholic faith. ${ }^{19}$ In the 18th century, Protestant dissenting churches or chapels catered especially to Welsh speakers. There were also important social reasons for the success of Welsh. The land-owning political elite of Wales was important in introducing English, but the Welsh language was preserved and developed by a rural middling sort (and a minor gentry) lacking in Scotland and Ireland..$^{20}$ In the 18th-century Highlands and Islands of Scotland, the cultural 'brokers' were often outsiders or outward looking: economic middlemen such as estate factors and mobile cattle drovers who favoured English or, more usually, Scots. ${ }^{21}$

What Wales lacked until the 18th century was a commitment to education in the Welsh language. ${ }^{22}$ When that came about through the actions of Griffith Jones, the movement stemmed from native Welshmen, rather than being imposed from outside by Anglicizers. Until then, there were English-language schools that had existed since the 16th century. ${ }^{23}$ Education was one of the domains where separate traditions of language use and literacy occurred: reading and writing in English, reading in Welsh. More generally, 'Although English was the dominant language in domains like government and administration, law, commerce, science and polite society, Welsh held sway on the hearth and in the workplace, in church and chapel, in literature and poetry, in recreation and popular culture. ${ }^{24}$

Whether Lutheran (as in Scandinavia and Germany), Calvinist (as in Scotland and the northern Netherlands) or Lutheran Pietist (as in German and Scandinavian 
lands from the late 17th century), religious change was a powerful force behind rising literacy and linguistic change. Across Europe, Protestant evangelists made religious literature available in the vernacular. A Lutheran prayer book and catechism were obtainable in Croat as early as 1601, Calvinist literature in Romanian from $c .1640$, Church Slavonic editions of the Lutheran catechism for use in Sweden's eastern territories in the second quarter of the 17th century. ${ }^{25}$ However, having a wide range of religious literature available in Low German at an early date did not prevent that dialect from being superseded by High German for religious and other purposes in the 17 th century. ${ }^{26}$

The reasons for the successes of certain tongues were as varied as the implications of using them. Speaking a separate tongue can be a sign of ethnic or political identity. ${ }^{27}$ But speaking the same language can also help to suppress particularism and this was the explicit or implicit policy of most early-modern governments. North-eastern 'French' (langue d'oïl), Castilian (castellano) and south-eastern 'English' spread because of their political dominance over adjacent regions. ${ }^{28}$ This was, however, a long-term process rather than the result of specific laws. English spread more rapidly to the Welsh gentry after their integration into the Commissions of the Peace, which were at the heart of the Tudor revolution in government during the 1530s and 1540s. Acts of 1536-43 united Wales with England and made English officially the language of government and justice, although it was already spoken by the upper classes long before this. ${ }^{29}$

The French crown also acted around this time with its 1539 ordinance of Villers-Cotterêts establishing langue d'oil (rather than Latin) as the official language of all French law courts. Importantly, neither piece of legislation actually proscribed Welsh or patois, even if they did seek to promote English or langue d'oil in certain administrative and political contexts. ${ }^{30}$ Low German decayed over time for reasons that apparently had little to do with politics, though they did with administration. ${ }^{31}$ Cosimo de' Medici promoted Tuscan while he was the first Grand Duke in the 16th century, but his political sway was not national. Tuscan was already spreading strongly in the 14th century - before Cosimo and before printing consolidated Tuscan's lead over other vernaculars - possibly thanks to the literary achievements of figures such as Dante and Boccaccio. ${ }^{32}$ Dante called Tuscan 'lingua di si' - the equivalent of French langue d'oill. Language followed the political fortunes of Castilian in the literary life of Catalonia and Galicia too, with most literature being produced in Latin or Castilian rather than the vernacular by the end of the 16th century. ${ }^{33}$

Not even literary languages were guaranteed permanence and spread. Scots had flourished as a literary medium in the late middle ages (c.1480-1520), but was in retreat thereafter as standard court Scots fragmented into regional dialects after the departure of James VI in $1603 .{ }^{34}$ The literati of Enlightenment Edinburgh aspired to pronunciation and orthography that conformed to the best London 
practice, as exemplified in the English man of letters Samuel Johnson's first English dictionary. ${ }^{35}$ Scots was used with confidence by late-18th-century poets such as Robert Fergusson and Robert Burns, and John Galt's early-19th-century novels were at least partly in Scots. While celebrated among contemporaries, the real significance of their work was for later Romantics and eventually nationalists. English rather than Scots (both Germanic tongues, the latter originally a standardized form of Northern Middle English) became the tongue of Scotland's landed, professional, and aspirant mercantile classes during the eighteenth century. ${ }^{36}$

There had been a tradition of poetry and medical writing in classical Gaelic, but (as in Ireland) this was too esoteric to give the language literary permanence, even when reinvigorated by more adventurous Scottish vernacular Gaelic. ${ }^{37}$ By the century's end, speakers of Gaelic were subjected to patronizing and anachronistic proto-anthropology, or were romanticized through the pseudoscholarship of Ossian. Only in the late Victorian period did Gaelic become identified with the backward and the boorish. Scots survived into the 19th and 20th century, but among the lower and middling orders and in the domains of the home, leisure and (manual) workplace. Scots was the victim of a social division in usage. It also suffered even before the 18th century because of Protestant promotion of religious literature in English. At the time of the Reformation, Protestants adopted English versions of the Geneva Bible and the English Form of Prayers as the Book of Common Order. The first authentically colloquial New Testament in Scots was not completed until two centuries after its Gaelic counterpart (four centuries after the Reformation) and was not published until $1983 .{ }^{38}$

Gaelic may not have been written off as early as Scots, but it had been viewed for centuries with far more hostility. The creation of a national identity in 16th and 17th century Scotland and of a British identity in the 18th century were at least partly tied up in the use of literacy and language as a way of reducing the influence of cultural forms held to be inimical to those identities. Specifically, the Gaelic language, a militaristic clan society, and a Catholic religion obtained in parts of the Highlands and Islands of Scotland. From the early 17th century, landowners there had been obliged to subscribe oaths of loyalty and bonds for peaceable behaviour which were not only written (the society relied largely on oral, aural and visual forms), but set down in a language different from the one they normally spoke. ${ }^{39}$ Literacy and language were used to integrate, but by excluding and seeking to dominate an 'other' - a different culture that was denigrated. ${ }^{40}$ Elsewhere in the British Isles similar ends came from different starting points. Late-17th-century debates in the Church of Ireland about whether to provide Protestant education in Irish or English fell out in favour of the latter. Ironically, the resulting policy did more to undermine the Gaelic language than it did the Catholic religion, which was its real end. ${ }^{41}$ Another contemporary 
Anglican campaign to theocratize and Anglicize, this time on the Isle of Man by Bishop Thomas Wilson, failed. Manx eventually yielded to English in the 18th century because of commercial interactions. ${ }^{42}$

In Scotland, Gaelic-speaking was certainly proscribed in schools by a Lowland-based government, which in 1615 described Gaelic as 'an unChristian language'. However, the decline of dialects and separate languages also occurred organically, as monoglots saw the economic advantages of speaking the national (or at least the dominant) language as well as (or in preference to) Gaelic. As in Ireland, there seems to have been no culturally inspired resistance to the spread of English in Scotland. On the contrary, it was eagerly sought out. Commercialization, evangelicalism and, eventually, military service for the British state further helped the penetration of English-language literacy. Furthermore, there were limits to the government's explicit or implicit pressures to conform in language. Legal processes involving Gaelic speakers could not have been conducted without some use of that tongue, and Scottish courts continued to provide translators for witnesses until well into the nineteenth century. ${ }^{43}$

This last point emphasizes that, to the surprise of some modern champions of linguistic diversity and/or separatism, the changing use of language cannot be seen as purely the result of proscription and reluctant surrender. To treat speakers of what became minority languages as solely the victims of a repressive process is to deny them independence and agency, however much we may understand their loss and hurt. ${ }^{44}$ Judged in their own terms, were they wrong to accept that their language and culture were a hindrance to personal advancement? Speaking, reading and writing English came to be seen as necessary to economic success and, ultimately, as a symbol of it. Models based purely on imposition and/or proscription have limited value, for a more or less willing reception must also be explained. Gaelic had probably been on the retreat in Scotland since the 12th or 13 th century, long before it was actively proscribed; perhaps Breton too. ${ }^{45}$ Scots too had been in decline before the reign of James VI, which is when English became truly established as a viable alternative to Latin as a medium of educated communication. It was further surrendered rather than suppressed as part of the Scottish Enlightenment's preference for communication and education in a 'properly' European language. ${ }^{46}$

It is, of course, possible to go too far in the direction of voluntarism. There is indeed a strain within Irish historiography which argues that 'the essential reason for the decline of Gaelic was the popular - or more precisely the Catholic popular - will' ${ }^{47}$ To this it may be objected that choices were limited in practice. In purely transactional terms, cattle merchants and others who dealt with the Gaidhealtachd or Gaeltacht should have learned Gaelic, for they were dealing with many Gaelic-speaking cattlemen. However, the dominance of English in legal, financial and other domains gave it an edge in the economic one. ${ }^{48}$ English-speaking 
(national) buyers had a more powerful negotiating stance than (regional) Gaelic-speaking producers and sellers.

In other countries, outright attempts at linguistic standardization largely failed. King Matthias's decree of 1615 making Czech the sole official language in his realm was a dead letter, partly because the German-speaking nobility rejected it. ${ }^{49}$ Some early-modern states lacked the political, bureaucratic or military apparatus to ensure their subjects' compliance. Examples are numerous. The Habsburgs repeatedly compromised with the Italian-speaking Tyrolese over the use of German in government and education; ${ }^{50}$ between 1773 and 1805 Polish and Prussian policies on the language of education in the Poznan region both recognized practical limitations. ${ }^{51}$ In some southern parts of France, royal edicts of 1700, 1735 and 1758 requiring French to be used in official documents were seemingly ignored. An attempt during the 1790s to impose French as the language of law (and French law) on the Rhineland was opposed for practical reasons by the legal establishment. ${ }^{52}$ Most states did not pursue active policies of linguistic conformity, even if they regarded them as desirable, and attitudes were rarely uniform or consistent over time. During the 1650s in Scotland, Presbyterian churchmen tried to make catechisms and psalters available in Gaelic. The initiative was not pursued when episcopacy returned in the 1660s, but was successfully revived in the 1690 s.

Where language policies changed with the regime, some peoples responded by becoming - or becoming more successfully - multi-lingual. Alpine areas show that formal education and political integration may be less significant to literacy than economics and religious heritage. They also demonstrate the creative adaptations that could be made by an apparently disadvantaged population. ${ }^{53}$ In contested interstitial regions, which frequently changed hands between the 16th and the 19th centuries - northern Italy is one example, Lithuania another - the languages of public affairs and education might change more than once in a generation. This may have hindered literacy in the short term, but helped it by embedding multi-lingualism in populations. ${ }^{54}$ Overlying this were more enduring cultural relations with a single culture such as German. The reasons why languages expanded, consolidated or contracted may, of course, be different over time and political or ecclesiastical policies were more important to these processes in the 18 th and 19th centuries than earlier.

Monolithic in theory, language policies were often more accommodating in practice. The Scandinavian countries (Denmark-Norway and Sweden-Finland) showed contrasting policies towards language and religious education in the 18th century, sometimes even within their own territories. In northern Norway and Finland, Lapps were taught reading in Norwegian. Lappish or Saami was not introduced as the language of religious instruction in Finnmark until 1820. In contrast, the Danish government favoured using the vernacular in missionary and 
educational contexts in Greenland, producing better results there than in Finnmark. ${ }^{55}$ Such literacy campaigns, aimed solely or primarily at reading and religious knowledge, enjoyed most success in politically, religiously and ethnically homogeneous countries such as Sweden.

Accommodation was the norm elsewhere too. The Court of Great Session, which tried serious criminal cases in Wales for three centuries after 1543, operated in English and Latin. At one level it was about centralization and Anglicisation. Yet for the first century of its existence it was extremely popular, as litigants saw this royal court as a way to overcome the influence of local patronage and faction in the distribution of justice. Furthermore, some Welsh procedures were allowed and there was probably extensive use of Welsh outside formal channels right up to the court's abolition in $1830 .{ }^{56}$ Practical exigencies and the determination of litigants to manipulate processes to their own ends tempered even apparently strict language policies. Ironically, some contributors to the debates on the future of the Court of Great Sessions in the late 1820s saw it as a symbol of Welsh separatism.

This illustrates that people can adapt positively and creatively to institutions and ideas that have retrospectively been classed as repressive and narrowing. Nor did a drive to standardize necessarily close off cultural possibilities. While the Revolutionary stress on a standard language like French may seem oppressive, it could act as a social leveller since elites tended to have patois and French, common people only patois. An important recent study of Breton is instructive. Negative official attitudes to the tongue were not enough to explain its decline. The reasons were that French offered access to learning and information; acquiring it made easier the experience of schooling and, eventually (in the 19th century), of military service; snobbery or social aping; and also from the late 18th century rejecting patois became a sign of modernity and liberation from traditional society. ${ }^{57}$ Beyond proscription, adopting a different tongue was part of a rational life strategy.

Even after the hard edge of some hegemonic policies had been softened, languages continued to decline, albeit at differing rates over time and space. When evangelical organizations, like the Society in Scotland for Propagating Christian Knowledge, turned their faces on two generations of proscription and began to use Gaelic for religious education from the end of the 18th century, they taught reading of the Scripture in Gaelic in their Highland schools. Pupils used this as a stepping stone to full literacy in English. The second half of the 18th century also saw a marked increase in Gaelic prose writings.

That Gaelic was given a marginal (if increasing) role did not necessarily counteract other forces causing it to decline (and keeping literacy low), any more than was ultimately the case with Breton. Gaelic was the first language of half of Scotland in the 15th century, a third in 1689, but just a fifth in 1806 and one-twelfth in 1900. The most rapid period of change came after active 
proscription of any kind had ceased. Gaelic speaking in the Highlands of Scotland continued to decline throughout the 19th century as people recognized the powerful advantages to be gained from literacy in English. Gaelic's decline provides an indication that even after active proscription had ceased, speakers might voluntarily abandon a language or dialect.

The varied effects that language policy could have are further illustrated in the case of Spain, which had one of the most heterogeneous language profiles in Europe. The diverse fortunes of tongues in the north-east and north-west of Spain are instructive. Literacy in Catalonia developed in Catalan during the 18th century, despite policies designed to promote Castilian - such as Charles III's decree of 1768 ordering that all governmental proceedings and public education be in that tongue. ${ }^{58}$ This was the first time that a concerted campaign had been waged, for when Aragon and Castile united in 1469 there was little effort to impose the latter's culture, except perhaps the 1715 Decreto de Nueva Planta. Indeed, it was not until the mid 19th century that a campaign to use Castilian for reading and writing began to be effective, and by that time Catalonian culture was undergoing a renaissance and separatists were explicitly rejecting Castilian. ${ }^{59}$

In Galicia as in Catalonia, Castilian was the language of the wealthy and powerful, while Catalan or Galician belonged to the masses. There were, however, subtle differences between the regions. Galicia had much less urban and industrial development than Catalonia. Where the Catalan bourgeoisie spoke Catalan, the urban middling ranks in the few large Galician towns, such as La Coruña (A Coruña in Galician) and Vigo, favoured Castilian. Castilian was taught in the best grammar schools of Catalonia in the 18th century, not because Catalan was proscribed in education, but because it was in demand. ${ }^{60}$ In Galicia, Castilian was also the language of schools, and people there learned to bow to the superiority of Castilian rather than actually learning to read and write it. Since the 17th century, Catalan had had a political significance that Galician lacked. ${ }^{61}$ Galician local elites were much more closely embedded in the central state than were their more independent Catalonian counterparts. But Galicia was different in other ways. For one thing it was poorer, and when school attendance statistics become available in the 19th century it had low levels of literacy, comparable with the deep south and much inferior to the north-east of Spain. Galicia also lacked the prosperous and independently minded rural middling sort found in Catalonia.

In the Russian empire, matters were also complicated. Literacy everywhere was low, and it is true that separate languages such as Ukrainian were proscribed from the 17 th century. However, before the emancipation of the peasantry in 1861 (and until the Revolution in some cases), Russia suffered from a distinctive combination of political, economic, and cultural circumstances that held literacy down. First, there began to develop in the 15th and 16th centuries, what became 
by the 18th century, a strictly-maintained divide between the vernacular and the esoteric language of learning - Church Slavonic - which had a different (Cyrillic) alphabet with a forest of accents and diacritic marks. Compounding this was a low level of urbanization and commercialization; pervasive serfdom with its restrictions on geographical and social mobility; elite antagonism to education of the peasantry; an absence of fixed rural schools (just 8000 with 450000 pupils in 1856 from a population of perhaps 75 million); and a relatively undeveloped printing industry. ${ }^{62}$

If there was an equivalent to Church Slavonic as an esoteric language of literacy in western Europe, it was Latin, the long-established international language of learning and of the learned. Latin readers, writers and speakers had been part of a pan-European culture in the age of the Renaissance. A privileged language of literary expression, Latin was a means of communicating between the educated classes, but it acted almost as a code for the 'illiteratus' - the medieval meaning was a person unable to speak, read, and write Latin. Vernaculars made rapid headway in some spheres. 'Spanish' replaced Latin as the language of popular religious learning during the 16th century, as shown by the tongue used when reciting prayers and articles before the Inquisition. ${ }^{63}$ Latin was a spoken language in academic and ecclesiastical circles (notably in Catholic Europe), and was used in some court transactions of the 16th and 17th century. However, Latin did persist as a principal language of scholarly engagement until the end of the 17th century and it was not until the second quarter of the 18th century that lecturing in English was introduced at some Scottish universities. Latin remained an official language in Hungary until the 1840s, but it is unclear whether it was widely (let alone accurately) spoken at any time in the previous three centuries. ${ }^{64}$

Having Latin made a person literatus. Other cultural divisions were expressed linguistically. Late-medieval western Hebraic book production contains almost no Latin works, probably because of the medieval association between Latin and Christian churchmen. Literary Hebrew was not the language most Jews spoke, meaning that 'the language of literary expression functioned as a genuine cultural barrier between Jews and Christians in Christian lands ${ }^{65}$ - western Jews too, until the 16th or perhaps 17 th century. The domains of the vernacular were defined as inferior to the sacred; for example, the vernacular was used for secular communication (including with Christians) and by women in almost all contexts. As the early modern period progressed, the vernacular became more of an integrating force among Jews as literacy in that medium spread. ${ }^{66}$ Hebrew remained an esoteric (sacred) language and few advances were made in Hebrew literacy, but its literature became more widely available in the vernacular - unlike in the east where the gap between the text in Hebrew, and most readers, only narrowed in the 20 th century. ${ }^{67}$ 
Esoteric languages could be maintained by clergy or adopted by social groups. Elites who used a language different from that of their inferiors could operate culturally at a national or even international level. For example, speaking, reading and writing French became a mark of sophistication, notably in Catholic Europe, in diplomatic circles and among the nobility of the Orthodox east. ${ }^{68}$ French was the new Latin. It was in use among merchants, students, officials and courtiers in the Netherlands from the 16th century and it became extensively used among social elites in the 17 th and 18 th centuries, much to the resentment of ordinary Dutch people. ${ }^{69}$ In the east, Catherine the Great was in favour of an edition of the Encyclopédie being printed in the Baltic city of Riga - but not in Russian. On its way to becoming a national language, French in an international context was an actively created 'minority' tongue. It was 'lesser-used' by being the preserve of a narrow (if dominant) social group as an explicit symbol of wealth, sophistication and breeding. ${ }^{70}$

Language was just one of the ways in which elites sought to mark themselves out as different from ordinary people. Castilian was increasingly important to the self-identity of the Catalan elite during the 17 th century. ${ }^{71}$ For the upper classes, different languages did not present an obstacle to literacy, but allowed different literacies to be developed. They used different varieties of language on different occasions, depending on the audience, setting, and topic. ${ }^{72}$ Such variations in language use are again well documented across early-modern Europe. The Norwegian written language of the middle ages - one of the languages of the sagas - had fallen into decay by the 16th century when Danish became the dominant written language. Danish was the language of the towns and of administration, Norwegian dialects belonged to the peasantry. In the west of Norway, the dialects resembled Icelandic (which remained a vital written and spoken language) and Faroese, in the east they resembled Swedish and Danish, making Danish readily intelligible in the east and the reception of Danish as a written language easier. What was called literary Norwegian after the political split of 1814 was almost the same as Danish. In 18th-century Finland too, rural dwellers spoke Finnish, more educated urbanites Swedish. However, Swedish itself was not yet standardized and $90 \%$ of 18 th-century Swedes used dialect for their day-to-day communications; the same is true of Finnish, as eastern and western dialects competed until the 19 th century to become an accepted Finnish literary language. ${ }^{73}$ These examples also remind historians that the battle for vernacular literacy did not necessarily bring all literate people into contact with printed or written material. The cost of buying books and the growing fashion for providing more advanced literature in languages that were not the vernacular opened up possibilities for the multi-lingual elites, but closed them off for many ordinary people. 


\section{Conclusions}

To summarize, regions in which dialects or separate languages persisted tended to be those with certain characteristics. Practical, religious or recreational literature was available in print. Religious and sometimes secular education was provided in the tongue most people spoke. The regions had a tradition of limited (if strongly felt) political independence that was recognized officially or unofficially by central government in the form of local or regional government institutions (including law courts) where 'minority' tongues were used or at least tolerated. Their level of economic development was not too far behind those of adjacent zones and they had a degree of urbanization; there were close and mutually beneficial ties between town and country. They possessed a relatively flat social structure with a middling rank, which used and was sympathetic to both 'dominant' and 'subordinate' languages.

All models simplify and early-modern Wales shows the limits of this one. It had no representative assembly, no university, no town of any size and England as a neighbour, but its native language endured better than most. ${ }^{74}$ In contrast, Low German was spoken in a region with many advantages, but its usage contracted. The erosion of Scots and Low German alike went side-by-side with high literacy in Lowland Scotland and northern Germany. ${ }^{75}$ But Portugal shows that linguistic unity and a literary language did not necessarily produce literacy. The Portuguese, with a vibrant national language (the sixth most widely spoken in the modern world), did not cross the threshold of $50 \%$ male literacy until after the Second World War. ${ }^{76}$

However one tinkers with the model to encompass as many diverse experiences as possible, it is important not to exaggerate the importance of active proscription of 'minority' languages. Beyond supra-national religious aspirations, language policy only became part of explicit drives to create a 'national' identity in most countries in the later 18 th and 19 th centuries. ${ }^{77}$ Education and literacy became weapons of assimilation: ways of indirectly persuading or directly forcing groups whose language was just one sign that they had not been integrated into the increasingly homogeneous power structure of the developing modern state. ${ }^{78}$ The aim was to enhance the fatherland by the use of a mother tongue. ${ }^{79}$ For example, German was forcibly reintroduced as the language of government and teaching in the Hungarian lands from 1849-67 following earlier efforts to Magyarize the country. ${ }^{80}$ From the 1880 s a revived campaign used Magyar in elementary schools while secondary schools taught 'national consciousness'. The country's 92 teacher training colleges used Magyar exclusively. However, this was not just against the German-speaking Austrian empire, but was also done at the expense of Rumanians, Ruthenians and Slovaks. The effect was slow to be felt. Around 1880, 14\% of Hungarians spoke Magyar, and the figure was 23\% in 1910, but, significantly, $90 \%$ of university students also spoke it. ${ }^{81}$ 
Explicit proscription or forced promotion was quite unusual in the early modern period. Languages and dialects declined sometimes as the result of a traumatic event, sometimes because of creeping erosion. Yet what became 'minority' languages never entirely disappeared and revivalist movements have always had cultural roots into which they could tap. Attempts to revive regional dialects, suppressed, 'deposed' or surrendered through political and economic change between the 16th and 18th centuries, began in the early 19th century. A Provençal revival led to the foundation in 1854 of the Félibrige - a society of regional poets who sought to codify and purify Languedocien and to restore its usage by promoting it in literary works. This was more a cultural than a politically separatist manifestation. The Félibes were Frenchmen first of all. They saw their movement as part of an attempt to assert national as well as regional identity within a larger Romance-speaking heritage. ${ }^{82}$

There was no necessary connection between language and national identity, but in Bulgaria and surrounding states language did become associated with nationalism in the 19th century. Bulgarian kiliyni or cell schools tended to cluster in regions of homogeneous Bulgarian speaking rather than of ethnic or linguistic transition. In the late 18th century Greek replaced Bulgarian in schools in peripheral places such as Târnovo and Sliven, creating considerable local hostility.

Movements to revive and remodel languages in the service of region or nation remained uncommon compared with the late 20th century. Those who now sponsor 'minority' tongues have a cultural statement to make about the merits of diversity and a political one about the validity of separatism. Less welcome, perhaps, is the notion that linguistic purism (be it Gaelic or French or whatever) can be equated with superior patriotism. In terms of practical language use, modern revivalist programmes resemble more closely the elitist multi-lingualism of Castilian and Catalan or Castilian and Galician rather than a true restoration of monoglottism. ${ }^{83}$ Nevertheless, modern revivals have been successful in implanting languages in the young, for even the more enduring tongues, such as Breton, were beginning to be confined to the older generations. ${ }^{84}$

In modern Scotland, the revival of Scots has come even later than Gaelic and has made little headway. Gaelic in modern Scotland is spoken by just $2 \%$ of the population (most of them in the urbanized region of Strathclyde), having been resuscitated in the guise of an independent 'national' language - though it was never spoken by all Scots (perhaps not even by a majority), even in the middle ages. It has assumed a positive political and cultural significance in the last 50 years that it never possessed in the previous 500 years. ${ }^{85}$ That Scots has arguably less of a claim to be a national language is partly because it more closely resembles English and partly because of the strong regional variations in its modern dialects 
which, despite flourishing literary and academic journals, hinder its acceptability. ${ }^{86}$ Scots exemplifies 'incipient standard languages that never fledged because they were ... superseded, amalgamated, or replaced by a related language of higher prestige, greater functional range and wider distribution' ${ }^{87}$

Scots has only very recently begun to be treated on a par with Gaelic in Scotland, although there have been vociferous campaigns by Ulster Scots to assert their separate (although strongly Protestant and British) identity through it (in opposition to Irish Gaelic, which has Catholic and nationalist connotations). Scots had expanded into Ulster in the 17th century with emigrants and more particularly as the language of estate management. Historically, Scots suffered a fate similar to Gallo in Upper Brittany. Even 19th-century antiquarians in search of the 'real' Brittany ignored this dialect of French because they regarded speakers as not true Bretons. A curious paradox arose. The same 19th- and 20th-century Breton nationalists, who decried the 'oppression' of the French language, called for the 'bretonnisation' of Upper Brittany. That meant forcing everyone in Brittany to speak Breton (certainly a separate language rather than a patois), even people whose ancestors, if they had ever spoken it, had not done so since the tenth century. ${ }^{88}$

In the early 21 st century, the perceived problem of lesser-used languages is that they are in decline and deserve saving in the interests of cultural diversity. In early-modern Europe the problem (if they perceived one) for governments and churches was the obstacle such languages seemed to present to instruction and integration. Importantly, however, the response of the church was not always to insist on standardization in a 'dominant' tongue. Sometimes churches used patois; sometimes they tried for a vernacular that would be accessible to the largest number. ${ }^{89}$ The problem for speakers was usually the need to acquire literacy in a language they did not normally speak in order to gain economic, cultural and, sometimes, political advantages.

Political choices work more than one way, and the persistence of certain languages may be understood in terms other than simply inertia. Preference for orality, and orality in a particular tongue, may have been a conscious or unconscious assertion of cultural priority. For example, in Brittany, Languedoc, southern Italy and north-west Spain, it was literacy itself as much as the language of literacy (langue d'oül, lingua di si or castellano) which was apparently shunned..$^{90}$ And the different language policies of Catholics and Protestants in France (Protestants favoured standardization around a dominant tongue) may have been at least partly a response to their perceptions of what could be achieved in the social and cultural milieu in which they operated.

Much work remains to be done on the reasons why individuals and groups make cultural choices to embrace one (then or later dominant) language or to stick to another (then or later subordinate) one. The process by which language change 
occurred is much better expounded for historic periods by socio-linguists than by historians. ${ }^{91}$ For example, if mothers are important in passing on language (" $l a$ langue maternelle'), do they make the decisions on what is taught in the home? ${ }^{92}$ Historians who approach these problems need to acknowledge that linguistic decisions may also be political statements, albeit ranging from the overt to the subtle. Voluntary decisions are almost always taken in contexts that limit the choices available. However, many models of cultural change rely too much on the advent of forces outside the existing social and cultural framework rather than on connections, adaptations and mutations within it. Saying that some peoples were robbed of their native tongue is as inaccurate and simplistic as saying that those who remained with, for example, Gaelic or Galician were merely backward and quaint.

\section{Acknowledgements}

I should like to thank Rob Bartlett, Jane Dawson, Esther Pascua Echegarry, Guðmundur Hálfdanarson, Anthony Lodge, Allan Macinnes, Niall Ó Ciosáin and Ian Press for their comments on earlier drafts. R. A. Houston, (2001) Literacy in Early Modern Europe: Culture and Education, 2nd edn, provides essential background information.

\section{Notes and References}

1. 10 Lower Hatch St., Dublin 2. E-mail: eblul@indigo.ie. Website: www.eblul.org.

2. F. Broudic (1995) La pratique du breton de l'ancien régime à nos jours (Presses Universitaires de Rennes), pp. 20-22.

3. D. A. Bell (1995) Lingua populi, lingua dei: language, religion and the origins of French Revolutionary Nationalism. American Historical Review, 100, 1404-1405.

4. G. Fitzgerland (1990) The decline of the Irish language. In M. Daly and D. Dickson (eds), The Origins of Popular Literacy in Ireland: Language Change and Educational Development, 1700-1920 (Dublin), p. 63. N. Ó Ciosáin (1997) Print and Popular Culture in Ireland, 1750-1850 (London), pp. 154-169.

5. L. Lunny (1990) Knowledge and enlightenment: attitudes to education in early-nineteenth-century east Ulster. In M. Daly and D. Dickson (eds), The Origins of Popular Literacy in Ireland: Language Change and Educational Development, 1700-1920 (Dublin), pp. 98-99. B. V. Michael (1982) The English language in Ireland. In R. W. Bailey and M. Görlach (eds), English as a World Language (Ann Arbor: University of Michigan Press), pp. 84-133.

6. S. G. Ellis (1999) The collapse of the Gaelic world, 1450-1650. Irish Historical Studies, 31, 464. 
7. P. Jenkins (1995) The Anglican church and the unity of Britain: the Welsh experience, 1560-1714. In S. G. Ellis and S. Barber (eds), Conquest and Union: Fashioning a British State, 1485-1725 (London), 122-123.

8. Broudic, La pratique du breton, pp. 33-58.

9. R. D. Grillo (1989) Dominant Languages. Language and hierarchy in Britain and France (Cambridge), p. 25. Bell, 'Lingua populi', pp. 1425-1430.

10. Broudic, La pratique du breton, pp. 181-183.

11. Y. Castan (1976) Les Languedociens du XVIIIe siècle et l'obstacle de la language écrite. Actes du 96e Congrès National des Sociétés Savantes, 1, 73-84. F. Furet and J. Ozouf (1982) Reading and Writing. Literacy in France from Calvin to Jules Ferry (Cambridge: Cambridge University Press), pp. 282-299.

12. G. Astoul (1996) L'instruction des enfants protestants et catholiques en pays Aquitains du milieu du XVIe siècle à la révocation de l'Edit de Nantes. Histoire de l'Education, 69, 60.

13. M. Görlach (1990) Scots and Low German: the social history of two minority languages. In M. Görlach, Studies in the History of the English Language (Heidelberg: Carl Winter [chapter first published 1985]), pp. 151-153. This does not mean that English or langue d'oül was the sole medium of Calvinist evangelization.

14. M. de Certeau, D. Julia and J. Revel (1975) Une ethnographie de la langue: l'enquête de Grégoire sur le patois. Annales E. S. C., 30(1), 3-41. M. de Certeau, D. Julia and J. Revel (1975) Une politique de la langue: la Révolution française et les patois (Paris). P. Achard (1980) History and the politics of language. History Workshop, 10, 175-183. P. L.-R. Higonnet (1980) The politics of linguistic terrorism and grammatical hegemony during the French revolution. Social History, 5, 41-69. M. Lyons (1981) Politics and patois: the linguistic policy of the French Revolution. Australian Journal of French Studies 18, 264-281. H. van Goethem (1989) La politique des langues en France, 1620-1804. Revue du Nord, 71, 437-460. F. Mombet (1981) Langue, moeurs et coutumes: une enquête historique. Revue de l'Agenais, 108, 29-45. Bell, Lingua populi, pp. 1416-1417. See also E. Weber (1977) Peasants into Frenchmen: the Modernization of Rural France, 1870-1914 (London). R. A. Lodge (1993) French: from Dialect to Standard (London: Routledge).

15. Ó Ciosáin, Print and Popular Culture, 163. The production of books remained stagnant in 17th-century Ireland and the primary source of new books was the import trade with England and Scotland. R. Gillespie (1988) Irish printing in the early seventeenth century. Irish Economic and Social History, 15, 81-88. See also G. H. Jenkins (ed) (1997) The Welsh Language before the Industrial Revolution (Cardiff).

16. Schemes to circulate Irish Gaelic Bibles were afoot in the 1690s, meaning that raw translation figures may be misleading. However, Irish and Scots Gaelic were not identical. I owe this information to Jane 
Dawson. Non-Presbyterian Protestant evangelists in late 18th and early 19th century Scotland used Gaelic as a medium of instruction. D. E. Meek (1987) Evangelical missionaries in the early nineteenth-century Highlands. Scottish Studies, 28, 1-34.

17. L. Guttormsson (1990) The development of popular religious literacy in the seventeenth and eighteenth centuries. Scandinavian Journal of History, 15, 12. G. Williams (1971) Language, literacy and nationality in Wales. History, 56, 12. G. Williams (1991) The Reformation in Wales (Bangor), pp. 27-28. S. Heininen (1990) Die Anfänge der finnischen Literatur. Nordeuropa, 26, 56-61. J.-F. Gilmont (1999) Protestant reformations and reading. In G. Cavallo and R. Chartier (eds), A History of Reading in the West, translated by L. G. Cochrane (Cambridge: Polity), p. 215.

18. P. Jenkins (1983) The Making of a Ruling Class: the Glamorgan Gentry, 1640-1790 (Cambridge), pp. 205-207.

19. É. Ó. Ciardha (1999) The Stuarts and deliverance in Irish and Scots-Gaelic poetry, 1690-1760. In S. J. Connolly (ed.), Kingdoms United? Great Britain and Ireland since 1500: Integration and Diversity (Dublin: Four Courts Press), p. 83.

20. See for example the argument of J. Gwynfor Jones (1997) The Welsh language in local government: justices of the peace and the courts of quarter sessions, c.1536-1800. in G. H. Jenkins (ed), The Welsh Language before the Industrial Revolution (Cardiff), pp. 181-206. R. Suggett (1997) The Welsh language and the court of great sessions. In G. H. Jenkins (ed), The Welsh Language before the Industrial Revolution (Cardiff), pp. 153-180, concludes that the law was not a contested domain of language use in early modern Wales.

21. In the 15th and 16th century the Gaelic learned orders had acted as cultural brokers, albeit for a restricted social circle. I owe this information to Jane Dawson.

22. E. M. White (1997) Popular schooling and the Welsh language, 1650-1800. In G. H. Jenkins (ed), The Welsh Language before the Industrial Revolution (Cardiff), pp. 319-341.

23. R. Webster (1990) Education in Wales and the rebirth of a nation. History of Education, 19, 183-194.

24. G. H. Jenkins, R. Suggett and E. M. White (1997) The Welsh language in early modern Wales. In G. H. Jenkins (ed), The Welsh Language before the Industrial Revolution (Cardiff), p. 122.

25. G. Borsa and L. Hadrovics (1982) Protestantische Werke in

Kajkavisch-Kroatischer Sprache aus der Druckerei des Joannes Manlius. Studia Slavica Academiae Scientarum Hungaricae, 28, 67-90. M. Dimik (1988) Primoz Trubar and the mission to the south Slavs. Slavonic and East European Review, 66(3), 380-399. J. V. Ecsedy (1993) Dobre Mester Erdélyi Nyomdája, 1640-42. Magyar Könyvszemle, 109, 146-166. K. Tarkiainen (1974) Den tidiga kyrkliga slavistiken i Sverige. Kyrkohistorisk Årsskrift, 4, 71-95.

26. Görlach, Scots and Low German, p. 152. M. Brecht (1994) 'Tosaginge' 
und 'Geloven': Neue Einsichten in die frühe Lutherrezeption in Hamburg. Archiv für Reformationsgeschichte, 85, 45-67. B. H. Spencer (2000) Variation, standardization, and language shift: the decline of Low German in the early modern period. University of Michigan, $\mathrm{PhD}$ thesis.

27. R. Bartlett (1994) The Making of Europe: Conquest, Civilization and Cultural Change (Harmondsworth: Penguin), 198-202.

28. In the case of Castilian, this had been happening since the 13th century in regions such as Murcia. D. Menjot (1995) Brassages linguistiques et langue écrite: le castillan dialectal de Murcie au bas moyen age. Le Moyen Age, 101, 447-449.

29. Williams, Language, literacy and nationality in Wales, pp. 4-5. P. R. Roberts (1997) Tudor legislation and the political status of 'the British tongue'. In G. H. Jenkins (ed), The Welsh Language before the Industrial Revolution (Cardiff), pp. 123-152.

30. Achard, History and the politics of language, pp. 175-6. Lodge, French, pp. 125-127. Bell, Lingua populi, p. 1410. Bell, Recent works, pp. 97-99. Bell argues strongly that there was no secular language policy in France until 1789, though he downplays certain important contrary evidence to make his case. P. Sahlins, (1989) Boundaries. The Making of France and Spain in the Pyrenees (Berkeley: University of California Press), pp. 116-119, 125. Broudic, La pratique du breton, pp. 262-264.

31. Görlach, Scots and Low German, pp. 146-151. In contrast, Scottish public records were the last domain to be Anglicized. See also H. L. MacQueen (1997) Linguistic communities in medieval Scots law. In C. Brooks and M. Lobban (eds), (1997) Communities and Courts in Britain, 1150-1900 (London: Hambledon), pp. 13-23.

32. P. Burke (1981) Languages and anti-languages in early modern Italy. History Workshop, 11, 29-31. A. Mazzocco (1977) The Italian connection in Juan de Valdés' Diálogo de la Lengua. Historiographia Linguistica, 24(3), 267-283.

33. D. de Courcelles (1998) Langue et pouvoir en Catalogne aux XVe et XVIe siècles. Nouvelle Revue du Seizième Siècle, 16(2), 197-218. M. Fernández (1997) Las primeras propuestas de 'seleccion de norma' para el Gallego: del padre Sarmiento a fines del siglo XIX. Historiographia Linguistica, 24(1-2), 139-157.

34. For example J. Galt (1822) The Entail, or the Lairds of Grippy (London, 1970 edition). J. D. McClure (1995) Scots and its Literature (Amsterdam: John Benjamins). J. D. McClure (1993) English in Scotland. In R. Burchfield (ed.), English in Britain and Overseas. Origins and Development (Cambridge: Cambridge University Press), 23-93. C. Jones (1995) A Language Suppressed. The Pronunciation of the Scots Language in the 18th Century (Edinburgh: John Donald). C. Jones (ed.) (1997) The Edinburgh History of the Scots Language (Edinburgh: Edinburgh University Press).

35. R. A. Houston (1999) Madness, morality, and creativity: Robert Fergusson and the social context of insanity in eighteenth-century 
Scotland. British Journal for Eighteenth-Century Studies, 22(1), 133-154. P. Fielding (1998) Writing at the north: rhetoric and dialect in eighteenth-century Scotland. Eighteenth Century: Theory and Interpretation, 39(1), 25-43. See A. Fox, Oral and Literate Culture in England, 1500-1700 (Oxford), pp. 53-64, for the roots of this trend towards standardisation in early modern England; pp. 64-72 deal with dialect. Similar developments were happening elsewhere in Europe. K. Savin (1999) Det övriga språket. Dialekter och dialektforskning i frihetstidens idévärld: en studie med utgångspunkt i Johan Ihres Swenskt Dialect Lexicon. Lychnos, 93-131. H.-J. Niederehe (1997) La gramaticografia del siglo XVIII: entre tradición y reorientación. Historiographia Linguistica, 24(1-2), 41-55.

36. S. Romaine (1982) The English language in Scotland. In R. W. Bailey and M. Görlach (eds), English as a World Language (Ann Arbor: University of Michigan Press), pp. 56-83.

37. A. I. Macinnes (1996) Clanship, commerce and the house of Stuart, 1603-1788 (East Linton), p. 2.

38. W. L. Lorimer (1983) The New Testament in Scots (Edinburgh). Lorimer completed his work in the 1960s. See D. A. Bell (2001) Culture and religion. In W. Doyle (ed.), Old Regime France, 1648-1788 (Oxford), pp. 82-83, for the growing divide between a court-standardized French and local dialects or bourgeois/peasant vocabulary and expression in literary language during the 17 th century.

39. V. E. Durkacz (1978) The Decline of the Celtic Languages (Edinburgh). C. W. J. Withers (1984) Gaelic in Scotland, 1698-1981 (Edinburgh). J. Dawson (1994) Calvinism and the Gaidhealtachd in Scotland. In A. Duke, G. Lewis and A. Pettegree (eds) Calvinism in Europe, 1560-1620 (Cambridge), pp. 231-253. Written culture was not absent from Gaeldom. Landowners had been using charters and entering into bonds of surety in Latin and Scots since the middle ages, and the tiny learned order were literate in Scots, Latin and Gaelic; Scots was the language of letter communication, even though both parties spoke (and could write) Gaelic. J. E. Dawson (ed) (1997) Campbell Letters, 1559-1583 (Edinburgh: Scottish History Society), pp. 7-8. MacQueen, Linguistic communities, pp. 19-20.

40. L. Colley (1992) Britons: Forging the Nation, 1707-1837 (New Haven: Yale University Press), pp. 12-14.

41. T. C. Barnard (1993) Protestants and the Irish language, c.1675-1725. Journal of Ecclesiastical History, 44(2), 243-272. J. Dawson (1995) Anglo-Scottish protestant culture and integration in sixteenth-century Britain. In S. G. Ellis and S. Barber (eds) Conquest and Union: Fashioning a British State, 1485-1725 (London), pp. 92-97.

42. P. Clamp (1988) Bishop Wilson's discipline: language schooling and confrontation in the Isle of Man, 1698-1755. Journal of Religious History, 15(2), 185-198.

43. For the use of translators at criminal courts in nineteenth-century Brittany see Broudic, La pratique du breton, pp. 59-72, 255. 
44. D. P. Pattanayak (1991) Literacy: an instrument of oppression. In D. R. Olson and N. Torrance (eds), Literacy and Orality (Cambridge), pp. 105-108.

45. Macinnes, Clanship, p. 76, notes that landowners from the central and northern Highlands had been schooling their sons in the Lowlands for generations before the Statutes of Iona and the 1616 Education Act, which condemned Gaelic as 'one of the chief and principal causes of the continuance of barbarity and civility'.

46. This point is ignored in Jones, A Language Suppressed, a book whose title rather begs the question. Görlach, 'Scots and Low German', pp. 150-151.

47. O. MacDonagh (1983) States of Mind: a Study of Anglo-Irish Conflict, 1780-1980 (London: Allen \& Unwin), p. 104. See also D. H. Akenson (1988) Small Differences: Irish Catholics and Irish Protestants, 1815-1922: an International Perspective (Kingston: McGill-Queen's University Press), 135-136: 'the Irish peasantry was shrewd enough to read the economic signs of the times' and switch to English. R. Hindley (1990) The Death of the Irish Language: a Qualified Obituary (London: Routledge), p. 13, refers to a 'collective decision' to change. I owe all these references to Niall Ó Ciosáin.

48. Compare interactions with independent trading nations around the world, where European merchants were usually obliged to learn, for example, Mandarin or Arabic, or at least to employ translators.

49. K. Adamová (1986) K otázce konfederacních snah v Ceském státe na pocítu 17. Století. Právnehistorické Studie, 27, 57-95.

50. M. J. Levy (1989) Language and politics: Habsburg cultural policy and Italian-speaking Tyrol's response, 1748-1795. Consortium on Revolutionary Europe, 1750-1850: Proceedings, 19(1), 139-153. See also L. Renzi (1981) La politica linguistica della rivoluzione francese (Napoli).

51. G. Harzheim (1992) Aspekte polnischer und preussischer Schulpolitik im posener Raum am Vorabend des Nationalismus. Bemerkungen zur Rolle von Sprache und Konfession in der Elementarschulpolitik. Nordost-Archiv, 1(2), 417-425.

52. Sahlins, Boundaries, p. 125. A. Grillo (1993) Sprache und Recht in den französischen Rheinlanden: die Einführung des Französischen als Gerichtssprache im Saardepartement, 1798. Rheinische Vierteljahrsblätter, 57, 227-252.

53. See also the discussion of the administrative independence of another Alpine area and its effects on literacy. A.-M. Granet-Abisset (1996) Entre autodidaxie et scolarisation: les Alpes briançonnaise. Histoire de L'Education, 70, 114. P. P. Viazzo (1983) Scuola e nomi di famiglia. In Alagna Valsesia: una comunità Walser, 162-169. See Sahlins, Boundaries, pp. 166-167, 264, for a Pyrenean comparison. M. Roggero (1990) L'istruzione di base i Piemonte tra antico regime e rivoluzione. Rivista Storica Italia, 102, 24-52.

54. Some possible outcomes are set out in R. C. Head (1995) A plurilingual 
family in the sixteenth century: language use and linguistic consciousness in the Salis family correspondence, 1580-1610. Sixteenth Century Journal, 26(3), 577-593. Among multi-lingual groups, a language might be chosen to enhance a particular type of writing. In part of eastern Switzerland, letters in Romansch were used for intimacy, Latin for formality, German for economic matters.

55. Guttormsson, The development of popular religious literacy, p. 27. K. Haugland (1980) An outline of Norwegian cultural nationalism in the second half of the nineteenth century. In R. Mitchison (ed.), The Roots of Nationalism in Northern Europe (Edinburgh), pp. 21-29.

56. Suggett, Great sessions, pp. 154, 165, 180. M. E. Jones (1998) 'An invidious attempt to accelerate the extinction of our language': the abolition of the Court of Great Sessions and the Welsh language. Welsh History Review, 19(2), 226-264. For the use of Breton at criminal courts in nineteenth-century Brittany see Broudic, La pratique du breton, pp. 61-2.

57. Broudic, La pratique du breton, pp. 38, 443.

58. P. Voltes Bou (1977) Carles III i el bandejament de la llengua catalana de la vida pública. Cuadernos de Historia Económica de Cataluña, 16, 55-58. Sahlins, Boundaries, pp. 125-127. D. D. Laitin, C. Solé and S. N. Kalyvas (1994) Language and the construction of states: the case of Catalonia in Spain. Politics \& Society, 22(1), 5-29.

59. A. Viñao (1990) The history of literacy in Spain: evolution, traits, and questions. History of Education Quarterly, 30, 573. A. Escolano (ed.) (1992) Leer y escribir en España. Doscientos años de alfabetización (Madrid: Ediciones Pirámide).

60. Sahlins, Boundaries, p. 127. E. Lluch (1999) Las Españas vencidas del siglo XVIII: claroscuros de la Ilustración (Barcelona: Editorial Crítica). Similarly, French speaking in Brittany was mainly an urban phenomenon until the 20th century. Broudic, La pratique du breton, pp. 56, 259-262, 441.

61. M. P. Benítez (1997) Literacy in Spain: research approaches and recent publications. Paedagogica Historica, 33(2), 507. Catalonia resembled pre-Revolutionary Brittany in having a strong tradition of political independence. Broudic, La pratique du breton, p. 251.

62. B. Eklof (1987) Russian literacy campaigns, 1861-1939. In R. F. Arnove and H. J. Graff (eds), National Literacy Campaigns: Historical and Comparative Perspectives (New York). B. Kharchuk (1989) Slovo i narod. Sucasnist, 3, 113-126. J. Brooks (1985) When Russia Learned to Read. Literacy and Popular Culture, 1861-1917 (Princeton).

63. S. T. Nalle (1992) God in La Mancha: Religious Reform and the People of Cuenca, 1500-1650 (Baltimore), pp. 122-123.

64. I. G. Tóth (2000) Literacy and Written Culture in Early Modern Central Europe (Budapest), pp. 133-144.

65. R. Bonfil (1999) Reading in the Jewish communities of western Europe in the middle ages. In G. Cavallo and R. Chartier (eds), A History of Reading in the West, translated by L. G. Cochrane (Cambridge: Polity), p. 166. 
66. R. Bonfil (1999) Reading in the Jewish communities of western Europe in the middle ages. In G. Cavallo and R. Chartier (eds), A History of Reading in the West, translated by L. G. Cochrane (Cambridge: Polity), p. 167.

67. R. Bonfil (1999) Reading in the Jewish communities of western Europe in the middle ages. In G. Cavallo and R. Chartier (eds), A History of Reading in the West, translated by L. G. Cochrane (Cambridge: Polity), p. 168. In Muslim areas Arabic was used for all forms of Judaic literature. See also J. Baumgarten (1996) La litterature Juive en langue Yiddish (16e-17e siècle): crise religieuse, culture vernaculaire et propagation de la foi. Annales E.S.C., 51(2), 491-511. C.

López-Morillas (1995) Language and identity in late Spanish Islam. Hispanic Review, 63(2), 193-210.

68. E. L. Eisenstein (1992) Grub Street Abroad: Aspects of the French Cosmopolitan Press from the Age of Louis XIV to the French Revolution (Oxford), pp. 38-40. G. Braun (1999) Frédéric-Charles Moser et les langues de la diplomatie Européenne (1648-1750). Revue d'Histoire Diplomatique, 113(3), 261-278.

69. W. Frijhoff (1989) Verfransing? Franse taal en Nederlandse Cultuur tot in de Revolutietijd. Bijdragen en Mededelingen, 104(4), 592-609. J. Ruwet and Y. Wellemans (1978) L'analphabétisme en Belgique (XVIIIe - XIXe siècles) (Louvain).

70. In view of French's later importance, it is ironic to consider that in the second half of the 16th century, Frenchmen like Jean Bodin defended their language and cultural identity against the perceived threat of dilution by Italian. M. Zylberberg (1996) Sentiment national et identité culturelle dans la France du XVIe siècle. Cahiers d'Histoire: Espaces Marx, 63, 7-29.

71. J. Amelang (1986) Honored Citizens of Barcelona: Patrician Culture and Class Relations, 1490-1714 (Princeton), 190-195.

72. Burke, Languages and anti-languages, pp. 24-25.

73. Savin, Det övriga språket, pp. 93-131. S. Kiuru (1988) Suomen kieli kirjallisuuden kielenä ennen Turun paloa. Opusculum, 8, 117-133.

74. Williams, Language, literacy and nationality in Wales, p. 10.

75. R. A. Houston, (1985) Scottish Literacy and the Scottish Identity (Cambridge: Cambridge University Press). A. Hofmeister, R. Prass and N. Winnige (1998) Elementary education, schools, and the demands of everyday life: northwest Germany in 1800. Central European History, 31, 329-384.

76. J. P. de Magalhães (2000) Lire et écrire dans le Portugal d'ancien régime. Paedagogica Historica, 36(2), 20.

77. P. Sériot (ed.) (1996) Langue et nation en Europe centrale et orientale du XVIIIème siècle à nos jours (Lausanne). Bartlett, Making of Europe, pp. 202-203, finds examples of forcible change in the middle ages.

78. D. A. Bell (1996) Recent works on early modern French national identity. Journal of Modern History, 68, 84-113.

79. As in the title of G. Hentschel (ed) (1997) Über Muttersprachen und Vaterländer (Frankfurt-am-Main). 
80. K. Fehér (1998) Reformkori sajtóviták a magyar tanítási nyelvrol. Magyar Könyvszemle, 114(2), 151-157.

81. J. K. Hoensch (1988) A History of Modern Hungary (London), pp. 30-1, 46-47. P. Király (1981) Der ruthenische Buchverlag in Ungarn und die Universitätsdruckerei von Ofen. Annales Universitatis Scientiarum Budapestinensis de Rolando Eötvös Nominatae: Sectio Historica 21, 13-22. R. Comtet and C. Karnoouh (1997) A propos de ... Langue et nation en Europe centrale et orientale du XVIIIe siècle à nos jours. Revue des Etudes Slaves, 69(3), 401-415. A. Feitsma (1975) Het Fries tot 1800. Spiegel Historiael, 10, 544-551.

82. J. Roza (1995) The Félibrige rouge and pan-latinism: ethnic identity without separatism. Proceedings of the Annual Meeting of the Western Society for French History, 22, 127-134. P. Pasquini (1997) L'apolitsme des parlers? A propos de 'Prouvençau e Catouli'. Provence Historique, 47, 301-316. R. Merle (1990) Fonction sociale du théâtre français et du théâtre dialectical dans le sud-est, de la fin de l'ancien régime à 1840 . Provence Historique, 40, 157-72. R. Bertrand (1997) Usage linguistique et textes en Provençal: travaux recents sur les XVIIe-XVIIIe et la première moitié du XIXe siècle. Provence Historique, 47, 339-346.

83. Fernández, Las primeras propuestas, 139-157, shows that the model of 'good gallego' in the 19th- and 20th-century revival of the tongue was that used by social elites.

84. Broudic, Qui parle breton, pp. 29-33.

85. C. Matheson and D. Matheson (2000) Languages of Scotland: culture and the classroom. Comparative Education, 36(2), 211-21. For comparison see F. Broudic (1999) Qui parle breton aujourd'hui?: Qui le parlera demain? (Brest: Brud Nevez).

86. B. Kay (1986) Scots: the Mither Tongue (Edinburgh: Mainstream).

87. Görlach, Scots and Low German, p. 144. It is important to stress that 'replacement' is often too simple a term to describe the interplay between languages. MacQueen, Linguistic communities, pp. 15, 19.

88. I owe this observation to Guðmundur Hálfdanarson of the University of Reykjavík.

89. Bell, Lingua populi, p. 1432.

90. J.-M. Sallmann (1989) Les niveaux d'alphabétisation en Italie au XIXe siècle, Melanges de l'Ecole Française de Rome: Italie et Méditerranée, 101, 191-192, 199. The quasi-structural illiteracy of southern Italy can be explained by the absence of a religious frontier, which meant that there was no need for a campaign to educate those tempted by a competing faith or to win back converts; the ambivalent attitude of elites to mass education; and limited geographical mobility and commercial exchange. M. R. Pelizzari (ed) (1989) Sulle vie della scrittura. Alfabetizzazione, cultura scritta e istruzioni in età moderna (Naples), pp. 635-636.

91. N. C. Dorian (1981) Language Death. The Life Cycle of a Scottish Gaelic Dialect (Philadelphia: University of Pennsylvania Press). N. C. Dorian (ed.) (1989) Investigating Obsolescence: Studies in Language Contraction and Death (New York: Cambridge University Press). J. A. 
Fishman et al. (eds) (1986) The Fergusonian Impact: in Honor of Charles A. Ferguson, 2 vols (Berlin: Mouton de Gruyter).

92. It should be noted that areas where regional languages were strong tended to have below-average literacy, and that in such areas female literacy tended to be particularly low.

\begin{abstract}
About the Author
Rab Houston is Professor and Chair of Modern History in the University of St Andrews. His work on education, language and literacy includes Literacy in Early Modern Europe: Culture and Education, 1500-1800 (2nd edn, 2001). His most recent books are Madness and Society in Eighteenth-Century Scotland (2000), Autism in History. The Case of Hugh Blair (2000) and The New Penguin History of Scotland (2001).
\end{abstract}

